Jurnal

\title{
Coronary Artery Fistula, an Unusual Cause of Chest Pain in Adult : Role of Computed Tomography Angiography
}

\author{
Prima Almazini, Andy Rahman, Dian Yaniarti, Elen Sahara, Celly Anantaria, \\ Manoefris Kasim
}

*Department of Cardiology and Vascular Medicine, Faculty of Medicine Universitas Indonesia

**Department of Cardiology and Vascular Medicine, Faculty of Medicine Universitas Andalas
Coronary artery fistula, usually congenital in origin, is an abnormal communication between a coronary artery and a cardiac chamber or great vessel. A coronary artery fistula can produce myocardial ischemia from coronary steal phenomenon. First case, a 54-year-old man was found to have a fistula from the left anterior descending coronary artery and right coronary artery to the main pulmonary artery, a rare anomaly. This patient developed chest pain due to myocardial ischemia in the left anterior descending coronary artery distribution for several months before evaluation. The patient was suggested to close the fistula but rejected. Second case, a-57 year-old woman was found to have fistula from left anterior descending coronary artery to main pulmonary artery. Patient presented with chest pain since 6 years ago. The patient was planned to close the fistula transcutaneously. Coronary artery fistulas, though rare, should be considered in the differential diagnosis when an adult patient presents with chest pain. Although coronary angiography is the gold standar diagnostic test for detection of coronary artery fistula, computed tomography angiography may be an alternative test through its good spatial resolution.

(J Kardiol Indones. 2015;36:209-19)

Keywords: coronary fistula, CT angiography, chest pain, diagnosis 
Jurnal

Kardiologi Indonesia

J Kardiol Indones. 2015;36:209-19

ISSN $0126 / 3773$

\title{
Fistula Arteri Koroner, Penyebab Nyeri Dada yang Jarang Ditemukan pada Dewasa : Peran Computed Tomography Angiografi
}

\author{
Prima Almazini, Andy Rahman, Dian Yaniarti, Elen Sahara, Celly Anantaria, \\ Manoefris Kasim
}

\begin{abstract}
Fistula arteri koroner, biasanya kongenital, merupakan komunikasi abnormal antara arteri koroner dan ruang jantung atau pembuluh darah besar. Fistula arteri koroner dapat menyebabkan iskemia miokardium melalui steal phenomenon. Kasus pertama, laki-laki 54 tahun didapatkan memiliki fistula arteri koroner dari arteri koroner left anterior descending (LAD) ke main pulmonary artery (MPA) dan right coronary artery (RCA) ke MPA, kelainan yang jarang. Pasien mengalami nyeri dada selama beberapa bulan karena iskemia miokardium di teritori LAD. Pasien disarankan untuk menutup fistula namun menolak. Kasus kedua, perempuan 57 tahun diketahui memiliki fistula arteri koroner dari LAD ke MPA. Pasien mengeluh nyeri dada sejak 6 tahun yang lalu. Pasien direncanakan penutupan fistula secara perkutan. Fistula arteri koroner, meskipun jarang, pertimbangkan sebagai diagnosis banding apabila pasien dewasa datang dengan keluhan nyeri dada. Meskipun angiografi koroner merupakan pemeriksaan standar emas untuk mendeteksi fistula arteri koroner, computed tomography angiografi menjadi pemeriksaan alternatif karena memiliki resolusi spasial yang baik.
\end{abstract}

(J Kardiol Indones. 2015;36:209-19)

Kata kunci: fistula koroner, CT angiografi, nyeri dada, diagnosis

A ngina pektoris merupakan sindrom berupa rasa tidak nyaman di dada, rahang, lengan, atau tempat lain yang dihubungkan dengan iskemia miokardium. Penyebab tersering iskemia miokardium adalah aterosklerosis koroner. Penyakit lain arteri koroner (emboli, spasme, vaskulitis,

\footnotetext{
Alamat Korespondensi

Prima Almazini, *Departemen Kardiologi dan Kedokteran Vaskular Fakultas Kedokteran Universitas Indonesia, **Departemen Kardiologi dan Kedokteran Vaskular Fakultas Kedokteran Universitas Andalas. Tel. +6285691869I 25.

E-mail:pri_zz@yahoo.com
}

penyakit jawasaki, kelainan kongenital), penyakit jantung lain (kardiomiopati hipertrofi, hipertensi berat, penyakit katup aorta berat), dan keadaan output yang tinggi (anemia berat, tirotoksikosis) adalah penyebab angina yang jarang. Angina biasanya dihubungkan dengan penyakit arteri koroner aterosklerosis, namun kenyataannya tidak selalu benar. Kondisi aterosklerosis koroner sangat sering, namun tidak selalu menyebabkan iskemia miokardium. ${ }^{1}$

Fistula arteri koroner merupakan salah satu kelainan arteri koroner kongenital yang dapat menimbulkan gejala angina. Fistula arteri koroner merupakan anomali anatomi baik kongenital maupun didapat 
dari arteri koroner ke ruang jantung atau pembuluh darah besar, tanpa melewati sirkulasi miokardium. Hubungan yang abnormal ini dapat menyebabkan gangguan hemodinamik yang signifikan, yang dapat mempengaruhi perfusi miokardium. ${ }^{2}$

Kelainan ini paling sering teridentifikasi secara insidental pada pasien dewasa dan pediatrik. Insiden kelainan ini yang sebenarnya sulit diketahui karena paling sedikit $75 \%$ kelainan ini asimptomatik dan secara klinis tidak diketahui hingga dilakukan ekokardiografi atau angiografi koroner. Penelitian di populasi menggunakan angiografi memperlihatkan insiden fistula arteri koroner hampir $0,3 \% .^{2}$

Insiden fistula koroner adalah $0,1 \%$ sampai $0,2 \%$ dari seluruh pasien yang dilakukan kateterisasi, peringkat kedua dari seluruh kelainan arteri koroner kongenital, yang pertama adalah kelainan asal dari arteri koroner. ${ }^{3}$ Baku emas pemeriksaan fistula arteri koroner adalah dengan angiografi koroner yang bersifat invasif. Pencitraan noninvasif dengan Computed Tomography (CT) merupakan alternatif yang baik untuk angiografi koroner. ${ }^{4}$

\section{llustrasi Kasus}

\section{Kasus pertama}

Pasien laki-laki, berusia 54 tahun, datang ke poliklinik Rumah Sakit Jantung dan Pembuluh Darah Harapan Kita (RSJPDHK) dengan keluhan dada terasa tidak nyaman. Keluhan dada terasa tidak nyaman dirasakan sejak 6 bulan terakhir. Keluhan muncul saat beraktivitas seperti naik turun tangga dan berkurang dengan beristirahat. Durasi keluhan kurang dari 10 menit dan tidak disertai penjalaran maupun keringat dingin. Sesak napas saat beraktivitas, tidak ada berdebar-debar. Faktor risiko pasien adalah hipertensi dan diabetes mellitus. Obat-obat yang diminum rutin adalah telmisartan/amlodipin $40 / 5 \mathrm{mg} 1 \times 1$ tablet, aspirin $1 \times 80 \mathrm{mg}$, atorvastatin $1 \times 20 \mathrm{mg}$, glimepirid $1 \times 1 \mathrm{mg}$, metformin $1 \times 850 \mathrm{mg}$.

Pada pemeriksaan fisik didapatkan tekanan darah 138/87 mmHg, frekuensi jantung $77 \mathrm{kali} / \mathrm{menit}$, frekuensi napas $20 \mathrm{kali} / \mathrm{menit}$. Status antropometri, berat badan $74 \mathrm{~kg}$, tinggi badan $165 \mathrm{~cm}$, indeks massa tubuh $27,18 \mathrm{~kg} / \mathrm{m}^{2}$. Pemeriksaan mata tidak ada konjungtiva anemis dan sklera ikterik, jantung terdapat bunyi jantung 1 dan 2 reguler, murmur kontinyu di batas sternum kanan atas menjalar ke batas sternum kanan bawah grade 3/6, paru suara napas vesikuler, tidak ada ronki dan mengi di kedua lapang paru, abdomen dan ekstremitas dalam batas normal.

Pemeriksaan EKG didapatkan irama sinus, frekuensi $85 \mathrm{kali} / \mathrm{menit}$, aksis ke kiri, gelombang $\mathrm{P}$ normal, interval PR 0.16 detik, durasi kompleks QRS 0,06 detik, T inverted di III, V1, tidak ada perubahan segmen ST dan hipertrofi (gambar 1).

Pasien dilakukan pemeriksaan exercise ECG pada bulan Mei 2015 dengan hasil respon iskemik negatif. Pemeriksan ekokardiografi pada bulan Mei 2015 memperlihatkan fungsi ventrikel kiri dan kanan normal, global normokinetik, katup dalam batas normal. Pemeriksaan CT angiografi pada 9 September 2015 memperlihatkan mild calcium plaque burden, mild stenosis di proksimal dan mid left anterior descending (LAD), minimal stenosis di distal LAD, fistula dari LAD ke main pulmonary artery (MPA) diameter 2,99

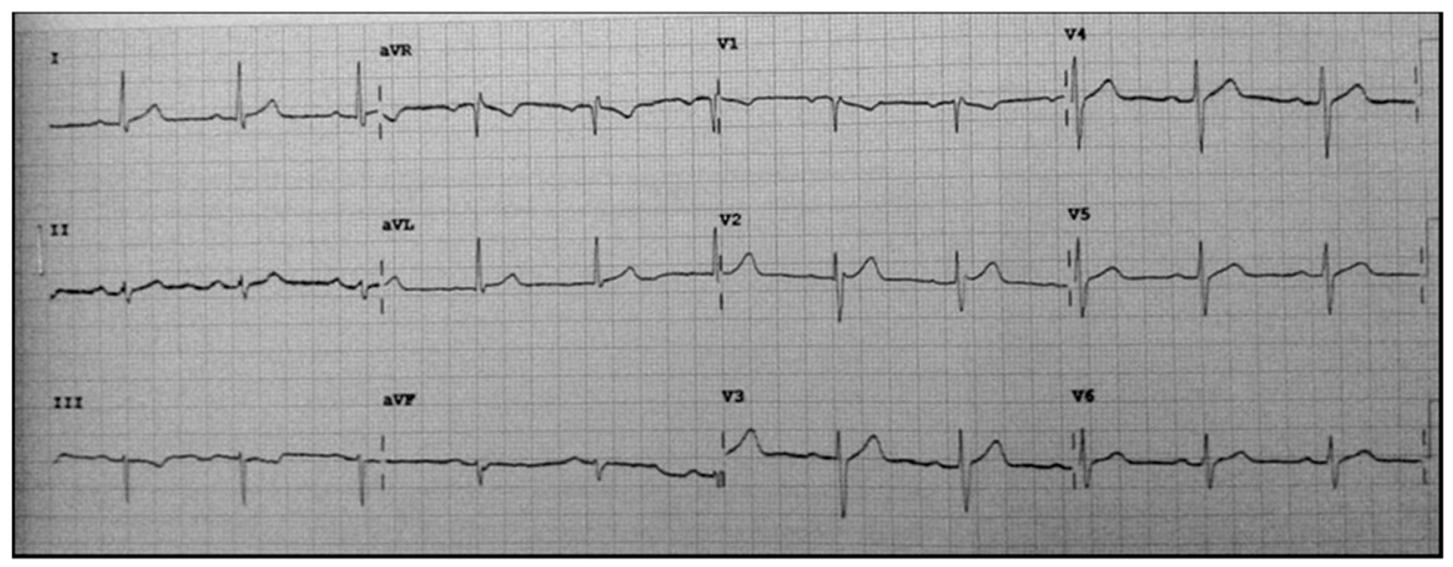

Gambar 1. Elektrokardiogram pasien tampak irama sinus tanpa perubahan segmen ST 
$\mathrm{mm}$ dan right coronary artery (RCA) ke MPA diameter $0,7 \mathrm{~mm}$ (gambar 2).

Pasien dilakukan pemeriksaan magnetic resonance imaging (MRI) pada 14 September 2015 didapatkan tidak ada edema miokardium, perfusi saat istirahat terdapat hipoperfusi ringan di basal septal, perfusi saat stres terdapat hipoperfusi moderat di basal-apikoseptal, basal-mid lateral. Suatu iskemia diinduksi oleh stres di basal-apikoseptal (teritori LAD) dan basal-mid lateral (teritori LCx), dan tidak ada jaringan skar (gambar 3).
Pasien didiagnosis Angina pektoris stabil Canadian Cardiovascular Society (CCS) II, Fistula LAD-MPA dan RCA-MPA, Diabetes Mellitus tipe 2, dan Hipertensi tipe 2. Pasien kemudian melakukan pemeriksaan koroangiografi di Rumah Sakit OMNI Alam Sutera pada 10 Oktober 2015 didapatkan left main (LM) normal; LAD normal, terdapat fistula dari proksimal LAD ke MPA; left circumflex (LCx) normal; right coronary artery (RCA) normal, terdapat fistula dari proksimal RCA ke MPA (gambar 4). Pasien disarankan untuk dilakukan tindakan penutupan
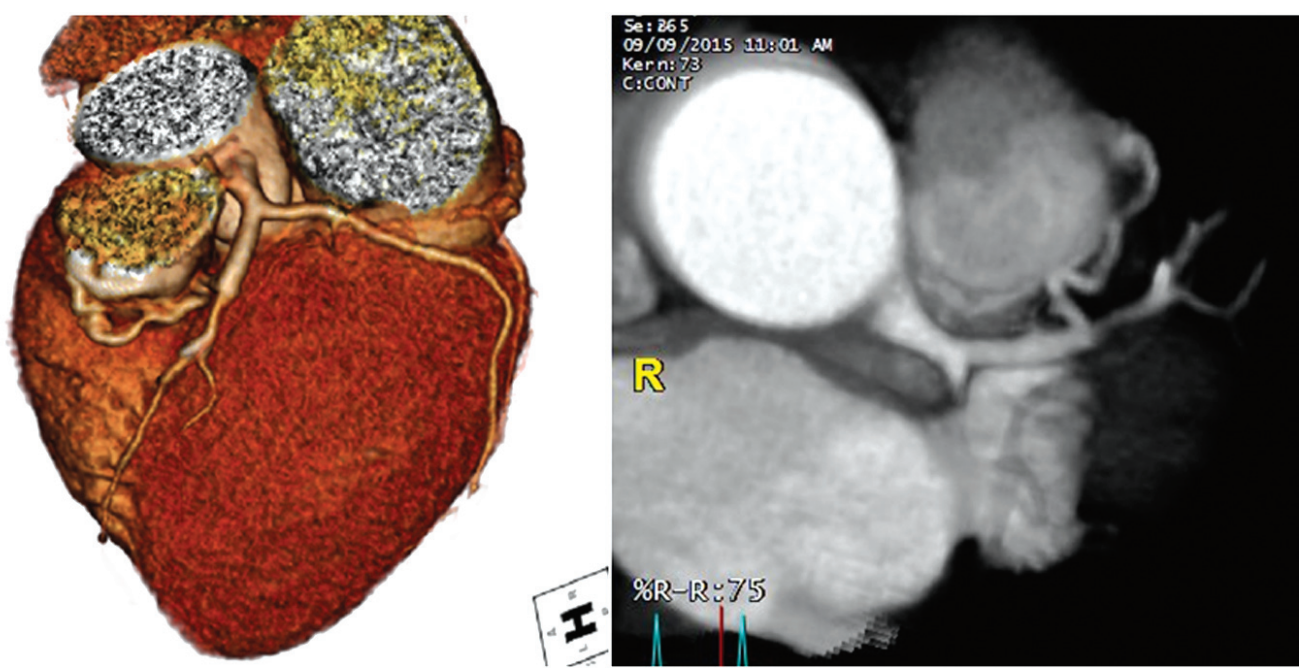

Gambar 2. Pada CT angiography tampak fistula koroner dari LAD ke MPA

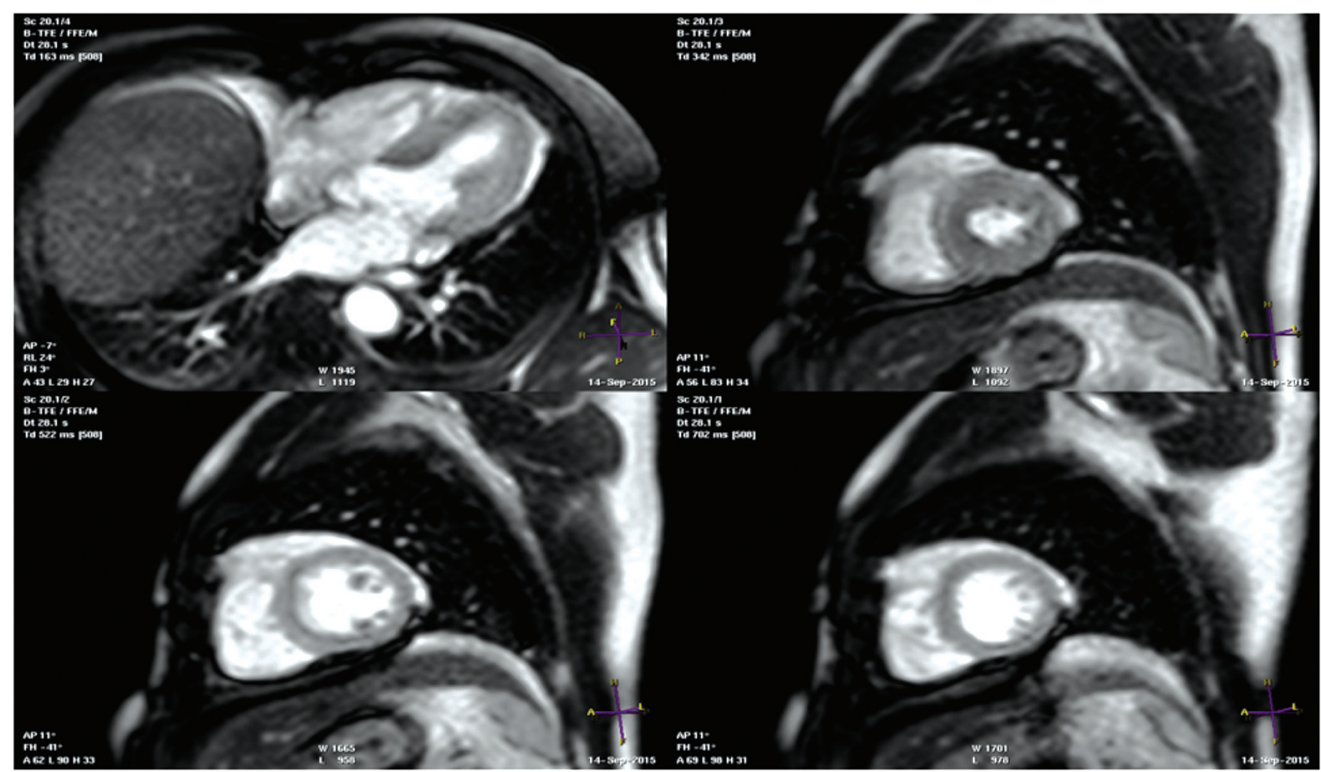

Gambar 3. Pemeriksaan perfusi MRI saat stres tampak hipoperfusi moderat di basal-apikoseptal, basal-mid lateral 


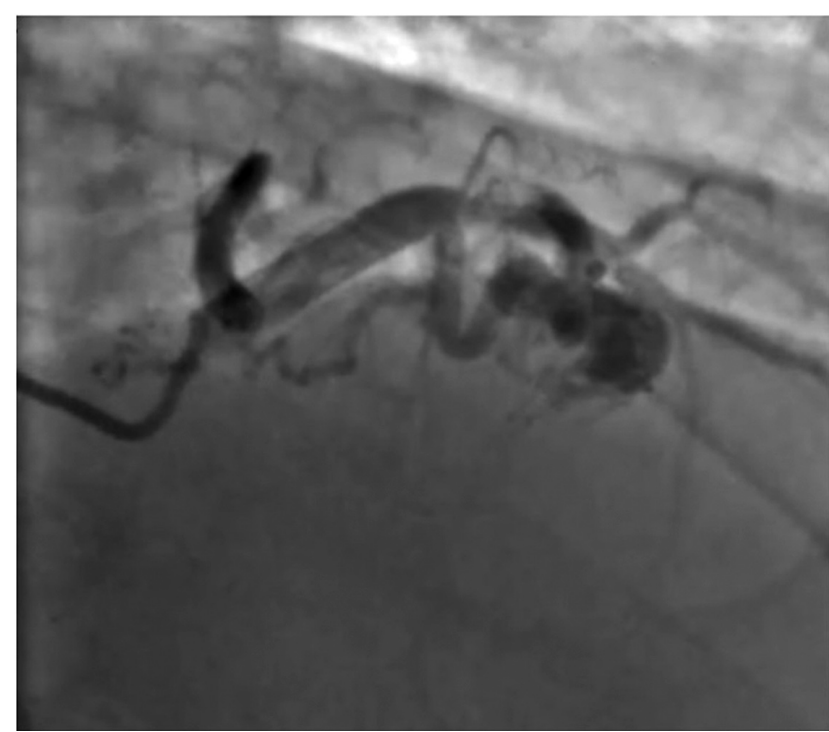

Gambar 4. Pada koroangiografi tampak fistula dari proksimal LAD ke MPA

fistula transkateter di RSJPDHK namun pasien menolak dilakukan tindakan.

\section{Kasus kedua}

Pasien perempuan, berusia 57 tahun datang ke poliklinik RSJPDHK dengan keluhan nyeri dada sejak 6 tahun yang lalu. Penjalaran ke punggung dan lengan, durasi 5-10 menit. Muncul ketika sedang beraktivitas seperti mandi, naik tangga, lama 5-10 menit, berkurang dengan istirahat. Pasien rujukan dari RS Awal Bros Bekasi dengan APS, VES/SVES, EF 67\%, dan hasil exercise ECG negatif. Faktor risiko pasien adalah hipertensi dan menopause.

Pada pemeriksaan fisik didapatkan berat badan 83 $\mathrm{kg}$, tinggi badan $153 \mathrm{~cm}$, IMT $35,45 \mathrm{~kg} / \mathrm{m}^{2}$, tekanan darah 142/73 $\mathrm{mmHg}$, frekuensi denyut jantung 76 $\mathrm{kali} / \mathrm{menit}$, frekuensi napas $16 \mathrm{kali} / \mathrm{menit}$, pemeriksaan mata konjungtiva tidak anemis, sklera tidak ikterik, pemeriksaan jantung bunyi jantung 1 dan 2 normal, tidak ada murmur dan gallop, pemeriksaan paru bunyi napas vesikuler, tidak ada ronki dan tidak ada mengi, pemeriksaan abdomen dan ekstremitas dalam batas normal.

Pada elektrokardiografi didapatkan irama sinus, frekuensi $75 \mathrm{kali} / \mathrm{menit}$, aksis normal, gelombang P normal, PR interval 0,16 detik, QRS duration 0,08 detik, $T$ inverted di III, V1, perubahan segmen ST dan hipertrofi ventrikel (gambar 5).

Pada pemeriksaan ekokardiografi di Rumah Sakit Mitra Keluarga Bekasi tahun 2012 didapatkan global normokinetik dengan fraksi ejeksi 67\%. Pemeriksaan exercise ECG di Rumah Sakit Mitra Keluarga Bekasi didapatkan respon iskemik negatif. Pemeriksaan holter di Rumah Sakit Mitra Keluarga Bekasi didapatkan VES dan SVES.

Pemeriksaan CT angiografi pada 12 November 2015 di RSJPDHK didapatkan minimal calcium plaque burden, minimal stenosis di proksimal LAD dan proksimal cabang Obtuse Marginal 1(OM 1), fistula proksimal LAD ke MPA diameter 3,85 mm (gambar 6).

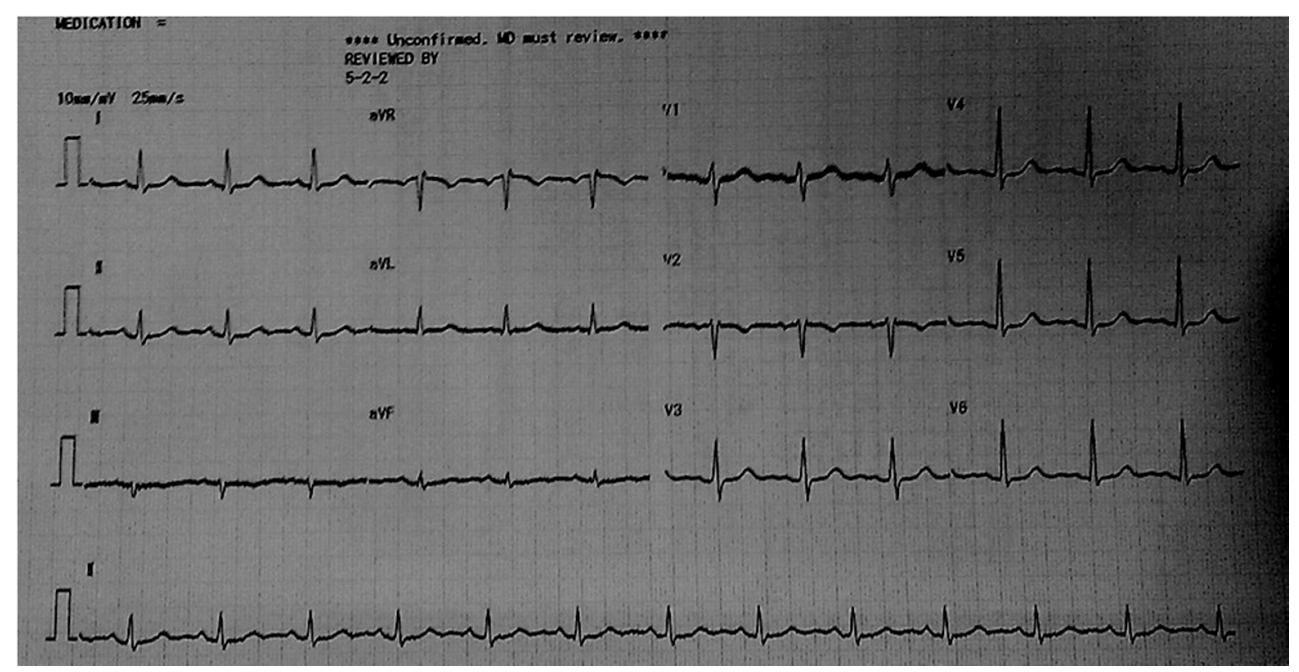

Gambar 5. Elektrokardiografi pasien memperlihatkan irama sinus tanpa perubahan segmen ST 
Pemeriksaan MRI pada 8 Desember 2015 di RSJPDHK didapatkan fraksi ejeksi ventrikel kiri $72,1 \%$, hipokinetik ringan di anterior, apikoseptal, edema di septal dan anterior, perfusi saat istirahat terdapat hipoperfusi ringan di basal-apikoseptal, basal-apikoinferior, basal-mid lateral, basal-mid inferior, perfusi saat stres terdapat hipoperfusi moderat di anterior dan septal, terdapat iskemia diinduksi stres di basal-apiko anterior dan septal, terdapat jaringan skar di basal-mid anteroseptal, apikoseptal dengan transmurality 50\%, perkiraan volume skar 2\% (gambar 7). Pasien didiagnosis Angina Pektoris Stabil CCS II, fistula LAD ke MPA, Hipertensi terkontrol. Pasien direncanakan penutupan fistula transkateter namun belum mendapatkan jadwal.

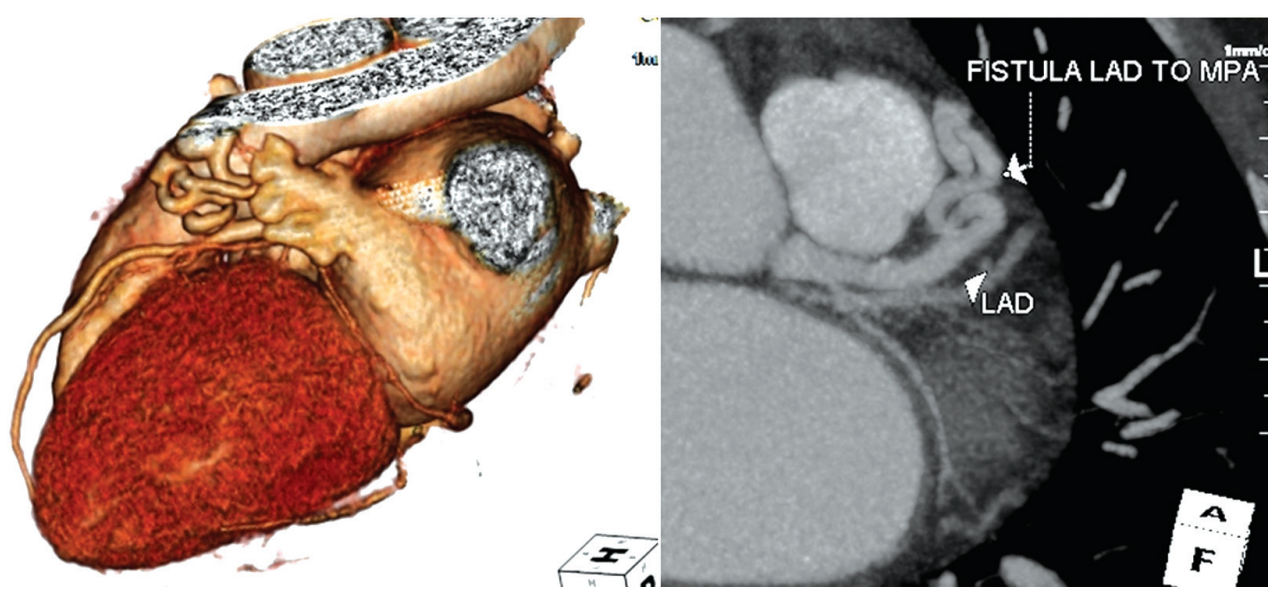

Gambar 6. Pemeriksaan CT angiography tampak fistula dari LAD ke MPA

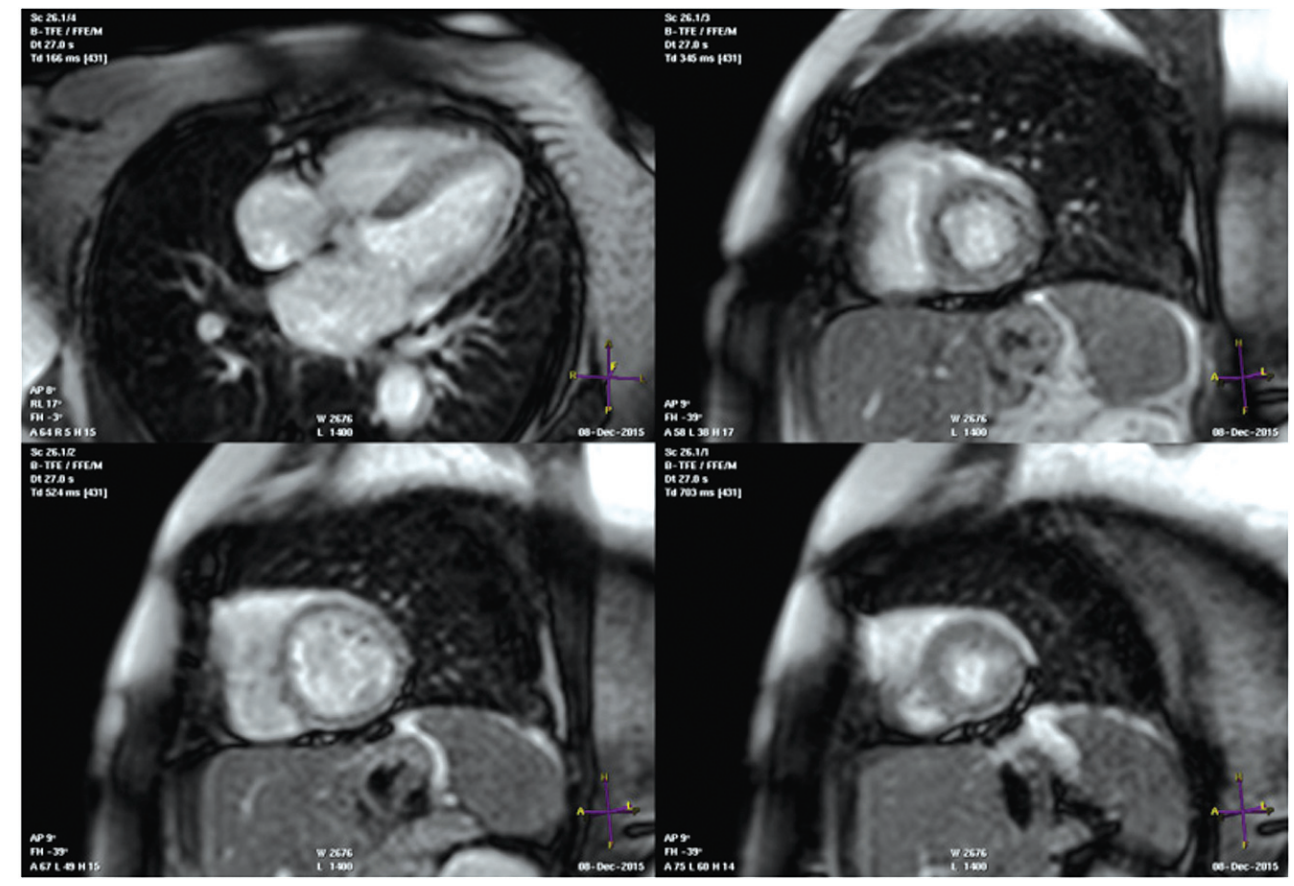

Gambar 7. Pemeriksaan perfusi MRI saat stres memperlihatkan hipoperfusi moderat di anterior dan septal 


\section{Diskusi}

\section{Pendekatan diagnosis gejala nyeri dada}

Terdapat 3 klasifikasi klinis nyeri dada, yaitu angina tipikal, angina atipikal, dan nonangina. Angina tipikal memenuhi seluruh tiga karakteristik yaitu dada terasa tidak nyaman di substernal dengan durasi dan kualitas, dipicu oleh aktivitas atau stres emosional, mereda dengan istirahat dan atau nitral dalam beberapa menit. Angina atipikal, apabila memenuhi dua dari karakteristik tersebut. Nyeri dada nonangina, apabila tidak memenuhi satu pun atau hanya satu karakteristik tersebut. Pasien pertama dan kedua mengeluh dada terasa tidak nyaman yang dirasakan dengan durasi 5 menit, tidak ada penjalaran, dirasakan bila beraktivitas, berkurang dengan istirahat atau nitral sublingual sehingga dikategorikan nyeri dada atipikal. Berdasarkan klasifikasi CCS kedua pasien dikategorikan kelas II.

Kedua pasien memiliki faktor risiko penyakit arteri koroner, sehingga penyebab angina dipikirkan karena penyakit arteri koroner. Berdasarkan panduan European Society of Cardiology (ESC) tahun $2013^{5}$, pada pasien yang dipikirkan memiliki penyakit arteri koroner stabil dilakukan pemeriksaan elektrokardiografi (EKG) dan ekokardiografi saat istirahat. Kedua pasien dilakukan pemeriksaan EKG dan ekokardiografi saat istirahat. Berdasarkan pretest probability (PTP) klinis pasien dengan gejala nyeri dada stabil, pasien pertama dan kedua memiliki PTP intermediet (pasien pertama $20 \%$, pasien kedua 49\%). Langkah selanjutnya adalah melakukan pemeriksaan noninvasif. Pada pasien dengan PTP intermediet dan fraksi ejeksi lebih dari $50 \%$, dilakukan exercise ECG atau pencitraan saat stress lebih direkomendasikan apabila terdapat fasilitas dan ekspertise lokal memadai. Pada pasien dengan PTP 15\%-50\% (intermediet rendah) dapat dilakukan computed tomography angiography (CT). ${ }^{5}$

Kedua pasien dapat melakukan aktivitas fisik dan memiliki EKG yang dapat dievaluasi sehingga untuk evaluasi gejala dilakukan pemeriksaan exercise ECG pada kedua pasien sebagai diagnostik awal, dengan hasil negatif iskemik respon pada kedua pasien. Kemudian pasien dirujuk ke RSJPDHK yang memiliki fasilitas CT angiografi dan pencitraan saat stress dengan MRI. Dari hasil pemeriksaan CT angiografi, pasien pertama didapatkan stenosis yang ringan dan fistula LAD-MPA serta RCA-MPA. Sedangkan pada pasien kedia, didapatkan stenosis minimal dan fistula LAD-MPA. Dari hasil pemeriksaan pencitraan perfusi MRI, pasien pertama didapatkan iskemia

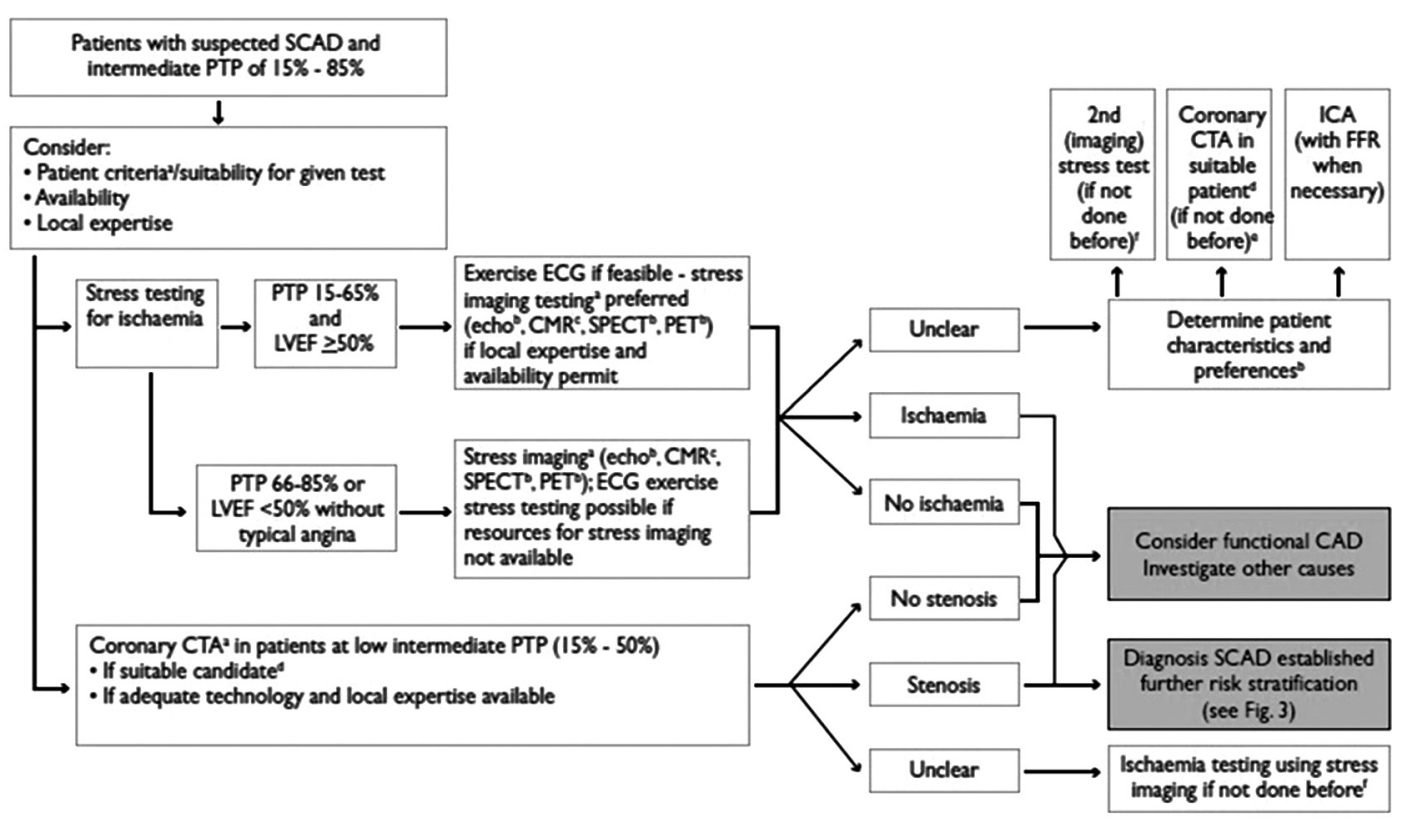

Gambar 8. Pemeriksaan noninvasif pada pasien suspek penyakit arteri koroner dengan intermediate PTP 
diinduksi oleh stres di teritori LAD dan LCx dan tidak ada jaringan skar. Sedangkan pada pasien kedua, didapatkan iskemia diinduksi stres di teritori LAD dan jaringan skar di basal-mid anteroseptal, apikoseptal dengan transmurality 50\%, perkiraan volume skar $2 \%$. Gambaran iskemia pada kedua pasien dipikirkan disebabkan oleh coronary stealing phenomenon dari fistula koroner.

\section{Gambaran klinis fistula arteri koroner}

Fistula biasanya dicurigai apabila murmur terdeteksi pada pasien asimptomatik. Prevalensi murmur kontinyu bervariasi pada laporan yang berbeda bergantung pada populasi yang diteliti. Lokasi dinding dada dimana murmur paling keras bergantung pada dimana fistula memasuki jantung. Dilaporkan bahwa murmur kontinyu ditemukan pada 3\%-9\% pasien dengan fistula. Karakteristik murmur yaitu lembut, derajat 2/6 sampai 4/6, murmur kontinyu cenderung crescendodecresendo pada sistolik dan diastolik tetapi lebih keras pada diastolik. Murmur sering mirip dengan kondisi lain, seperti pasien patent ductus arteriosus (PDA), pirau arteriovena, fistula arteriovena pulmonal, ruptur aneurisma sinus valsava, aortopulmonary window, prolapse cusp aorta kanan dengan ventricle septal defect (VSD) suprakristal, fistula arteri mamaria internal ke arteri pulmonal, dan fistula arteriovena sistemik. Pada kondisi-kondisi tersebut, murmur kontinyu mencapai intensitas puncak pada bunyi jantung dua. Fistula arteri koroner perlu dipikirkan pada banyak pasien simptomatik atau asimptomatik dengan murmur kardiak. $^{6}$

Riwayat perjalanan alami fistula arteri koroner bervariasi, dengan periode stabilitas panjang pada beberapa pasien dan progresivitas gejala yang gradual atau mendadak pada pasien yang lain. Tipe fistula, volume pirau, tempat pirau, dan terdapat kondisi kardiak lain dihubungkan dengan gambaran klinis fistula. Apabila fistula arteri koroner biasanya asimptomatik karena aliran pirau kecil, fistula arteri koroner besar, sebagian besar simptomatik menyebabkan gagal jantung, hipertensi arteri pulmonal, infark miokardium, aritmia, endokarditis, atau ruptur. Gejala fistula pada dewasa biasanya dimulai pada dekade ke-5 atau ke-6. Meskipun gejala dan komplikasi fistula arteri koroner berukuran besar jarang pada anak, gejala dapat terlihat pada usia 20 tahun. Pada sebuah artikel disebutkan bahwa sebagian besar pasien dengan fistula yang lebih muda daripada
20 tahun asimptomatik dibandingkan dengan pasien lebih tua dari 20 tahun. $^{7}$

Beberapa gejala disebabkan oleh sejumlah darah yang berpindah dari kiri ke kanan dan lainnya oleh hipoperfusi koroner dari steal phenomenon. Gejala paling sering pada dewasa adalah angina (khususnya jika terdapat penyakit arteri koroner), infark miokardium, gagal jantung, aritmia, dan endokarditis. Gejala iskemik pada fistula disebabkan oleh coronary steal phenomenon. Iskemia miokardium telah dilaporkan pada beberapa pasien dengan fistula arteri koroner meskipun tanpa bukti aterosklerosis. Pasien dengan angina pektoris biasanya lebih dari 40 tahun dan memiliki stenosis arteri koroner dan atau memiliki fistula yang besar atau multipel. Selain itu, sejumlah kecil fistula besar terdokumentasi mengalami aneurisma dan bahkan diseksi atau ruptur. Presentasi yang jarang namun dapat terjadi yaitu efusi perikardial dan kematian mendadak. ${ }^{8}$ Jika terdapat pirau dari kiri ke kanan yang besar, komplikasi yang dapat terjadi adalah hipertensi pulmonal, gagal jantung kongestif dan ruptur atau trombosis fistula atau dihubungkan dengan aneurisma arterial (19\%-26\%). ${ }^{9}$

\section{Diagnosis fistula arteri koroner}

Metode diagnosis yang paling sering biasanya meliputi pemeriksaan fisik, elektrokardiografi, roentgen thoraks, ekokardiografi, CT, MRI, dan angiografi. Meskipun elektrokardiogram memperlihatkan beban volume ventrikel kiri dan kadang-kadang perubahan iskemia, biasanya tidak membantu diagnosis fistula. Secara umum, roentgen normal, tetapi kardiomegali moderat kadang-kadang mungkin saat terdapat pirau kiri ke kanan besar. Evaluasi exercise ECG fungsi koroner tidak lagi dipakai karena hasil yang konsisten insiden tinggi hasil positif palsu dan negatif palsu. Hal ini mengapa exercise ECG jarang digunakan dan tidak reliabel. MRI dan scintigrafi perfusi miokardium dapat digunakan untuk menilai iskemia miokardium dan setelah terapi fistula. ${ }^{10}$

Angiografi koroner merupakan teknik diagnostik utama yang lebih detail untuk diagnosis fistula dan implikasi dinamiknya, yang tidak dapat terlihat seluruhnya dari pemeriksaan noninvasif. Kateterisasi jantung dan angiografi telah digunakan sebagai metode evaluasi fistula. Kateterisasi digunakan untuk mengevaluasi hemodinamik fistula. Kateterisasi jantung menjadi modalitas pilihan untuk melihat pola struktur dan aliran arteri koroner. Pada sebagian 
besar fistula, tekanan intrakardiak normal dan aliran pirau kecil. Aortografi atau arteriografi koroner selektif memberikan anatomi fistula paling detail, khususnya ukuran, asal, perjalanan, adanya stenosis dan tempat drainase. Selain itu, embolisasi terapeutik menggunakan koil oklusif atau device dapat dilakukan melalui kateterisasi. ${ }^{11}$

Angiografi koroner masih menjadi standar emas untuk pencitraan arteri koroner, tetapi kadang-kadang asal dan hubungan fistula dengan struktur jantung di sekitarnya ambigu. Sulit untuk mengukur dan mengobservasi pembuluh darah turtous abnormal dengan angiografi koroner pada satu bidang, pada kondisi tersebut metode noninvasif seperti transtorakal dan transesofageal ekokardiografi, MRI, dan CT dapat digunakan untuk membantu angiografi koroner.

Ekokardiografi membantu dalam mendiagnosis fistula. Ekokardiografi dua dimensi akan memperlihatkan pembesaran atrium kiri dan ventrikel kiri sebagai konsekuensi aliran pirau signifikan atau disfungsi global atau regional berkurang sebagai konsekuensi iskemia miokardium. Arteri koroner membesar bermakna dapat terdeteksi dengan ekokardiografi. Ekokardiografi tidak cocok untuk evaluasi status fungsional fistula. ${ }^{12}$

Ekokardiografi transesofageal dapat sangat berguna untuk identifikasi noninvasif fistula koroner, khususnya mengidentifikasi asal, perjalanan, dan tempat drainase fistula. Agen ekokontras microbubble dapat digunakan bersama dengan ekokardiografi transesofageal untuk meningkatkan visualisasi. ${ }^{13}$

Meskipun ekokardiografi sering digunakan untuk mendeteksi fistula arteri koroner, evaluasi yang detail mungkin sulit dilakukan pada beberapa pasien. Pasien dengan berat badan besar sulit untuk diperiksa karena acoustic window yang tidak cukup untuk ekokardiografi. Kateterisasi jantung merupakan metode diagnostik terbaik untuk identifikasi fistula, tetapi invasif dan dapat menimbulkan morbiditas $1,5 \%$ dan mortalitas $0,15 \%$. Oleh karena itu, pasien yang dilakukan ekokardiografi dan angiografi tidak dapat memberikan informasi anatomi dan fisiologi, CT akan memberikan informasi tambahan fistula, mendapatkan informasi untuk perencanaan terapi yang lebih optimal. Gambaran pembuluh darah distal oleh CT dapat menilai ada tidaknya obstruksi yang menentukan presentasi steal arteri koroner. Opasifikasi kontras ke ruang/pembuluh darah digunakan dalam mengkonfirmasi entri fistula dan patensi pirau. ${ }^{14}$

CT membutuhkan waktu yang lebih sedikit daripada kateterisasi dan membutuhkan kemampuan yang lebih sedikit. Risiko kateter, termasuk perdarahan pada tempat pungsi, pembentukan hematoma, kejadian fistula arterivena dan lain-lain. Hal ini juga menghilangkan komplikasi yang lebih serius kateterisasi seperti diseksi arteri dan stroke. Prosedur dilakukan dalam setting poliklinik dan perawatan tidak diperlukan. ${ }^{14}$

CT dapat memberikan gambar anatomi resolusi tinggi dengan menggunakan rekonstruksi ECGgated. Gambar CT memperlihatkan fistula yang membesar dan evaluasi dilatasi aneurisma atau pembentukan trombus pada pembuluh darah. Gambar volume-rendered didapatkan dari CT 3 dimensi memberikan gambaran anatomi kardiak dan vaskular dan membantu dokter bedah memahami kompleksitas anatomi sebelum pembedahan. CT dipertimbangkan menjadi alternatif yang baik terhadap ekokardiografi dan angiografi koroner. Keterbatasan utama CT adalah pajanan radiasi. ${ }^{14}$

Pada kedua pasien ini, ekokardiografi tidak memperlihatkan adanya fistula dan exercise ECG tidak memperlihatkan adanya iskemia. Exercise ECG memiliki sensitivitas yang rendah (45\%-50\%), meskipun spesifisitasnya cukup tinggi 85\%-90\%. Oleh karena itu banyak hasil exercise ECG yang tidak akurat. Pada pemeriksaan CT didapatkan gambaran fistula arteri koroner dan dibuktikan dengan adanya iskemia pada perfusi MRI. CT memungkinkan pencitraan anatomi yang sangat baik dengan resolusi yang tinggi sehingga pada kedua pasien dapat ditentukan asal, perjalanan, tempat drainase serta ukuran diameter fistula. Fistula arteri koroner merupakan penemuan yang tidak diharapkan sebelumnya pada kasus ini. Hal ini sesuai dengan banyak literatur bahwa lesi ini sering didiagnosis secara insidental.

\section{Terapi fistula arteri koroner}

Berbagai pendekatan telah digunakan untuk penatalaksanaan fistula arteri koroner. Gejala klinis iskemia seperti nyeri dada saat beraktivitas, sesak napas, merupakan indikasi primer penutupan fistula. Masih terdapat kontroversi mengenai penatalaksanaan fistula tanpa adanya gejala. ${ }^{13}$

Penutupan fistula koroner dapat dilakukan dengan berhasil apabila fistula arteri koroner dapat ditelusuri dengan baik dan akses bedah secara teknik diyakini dapat dilakukan. Rekurensi menjadi masalah jika anatomi belum jelas dan bedah akan kesulitan untuk 
dilakukan karena visualisasi yang buruk, terutama hubungan fistula distal. Penutupan secara bedah fistula arterivena koroner yang terdengar dengan anatomi yang tepat direkomendasikan pada semua fistula arterivena koroner besar dan pada yang kecil sampai sedang dengan adanya gejala iskemia miokardium, iskemia, aritmia yang mengancam nyawa, disfungsi ventrikel yang tidak diketahui sebabnya, atau hipertensi atrium kiri. ${ }^{3}$

Berbagai laporan penutupan transkateter dengan koil atau device memperlihatkan penutupan komplit atau hampir komplit oklusi fistula. Kriteria untuk penutupan transkateter fistula arteri koroner sama dengan kriteria bedah. Penutupan fistula transkateter sebaiknya dilakukan hanya pada pusat pelayanan yang berpengalaman dalam intervensi ini. ${ }^{3}$

Ligasi bedah fistula aman dan efektif, dengan hasil yang baik. Embolisasi transkateter merupakan pilihan terapi nonbedah. Hasil dari embolisasi transkateter dan ligasi bedah memperlihatkan bahwa kedua pendekatan memiliki efektivitas, morbiditas, dan mortalitas awal yang sama. ${ }^{15}$
Pada kedua kasus, pasien memiliki gejala dan ditemukan adanya iskemia pada pemeriksaan perfusi MRI, sehingga merupakan indikasi untuk dilakukan penutupan fistula. Pasien pertama menolak dilakukan tindakan, sedangkan pasien kedua bersedia dilakukan penutupan transkateter namun belum mendapatkan jadwal tindakan.

\section{Ringkasan}

Dilaporkan dua orang pasien dengan keluhan nyeri dada atipikal yang dipikirkan disebabkan oleh penyakit arteri koroner. Pemeriksaan noninvasif dengan CT angiografi memperlihatkan terdapat fistula arteri koroner dengan stenosis arteri koroner yang tidak signifikan. Diagnosis fistula arteri koroner ditegakkan secara insidental saat dilakukan pemeriksaan untuk mendiagnosis penyakit arteri koroner stabil. Fistula arteri koroner, meskipun jarang, perlu dipertimbangkan sebagai diagnosis banding apabila pasien dewasa datang dengan keluhan nyeri dada. CT angiografi

Tabel 1. Rekomendasi panduan penyakit jantung kongenital pada dewasa tahun 2008 mengenai fistula arteri koroner ${ }^{3}$

\begin{tabular}{|l|}
\hline Kelas I \\
\hline Jika terdapat murmur kontinyu, asalnya harus ditentukan baik melalui ekokardiografi, MRI, CT angiograf, atau kateterisasi. (C) \\
\hline $\begin{array}{l}\text { Fistula arterivena koroner besar, tanpa melihat ada tidaknya gejala, sebaiknya ditutup melalui baik transkateter atau bedah setelah menelusuri } \\
\text { perjalanan fistula dan kemungkinannya untuk menutup fistula. (C) }\end{array}$ \\
\hline $\begin{array}{l}\text { Fistula arterivena kecil sampai sedang dengan terdapat iskemia miokardium, artimia, disfungsi ventrikel atau diastolik yang etiologinya tidak } \\
\text { diketahui atau pembesaran ventrikel atau endarteritis sebaiknya ditutup melalui baik transkateter maupun bedah setelah menelusuri perjalanan } \\
\text { fistula dan kemungkinannya untuk menutup fistula. (C) }\end{array}$ \\
\hline Kelas IIa \\
\hline $\begin{array}{l}\text { Tindak lanjut klinis dengan ekokardiografi setiap } 3 \text { sampai } 5 \text { tahun dapat bermanfaat untuk pasien dengan fistula arterivena koroner kecil dan } \\
\text { asimptomatik untuk menyingkirkan adanya gejala atau aritmia atau pertambahan ukuran atau pembesaran ruang yang dapat mengganggu } \\
\text { penatalaksanaan. (C) }\end{array}$ \\
\hline Kelas III \\
\hline Pasien dengan fistula arteri koroner kecil asimptomatik sebaiknya tidak dilakukan penutupan fistula. (C) \\
\hline
\end{tabular}

Tabel 2. Rekomendasi panduan penyakit jantung kongenital pada dewasa tahun 2008 mengenai strategi penatalaksanaan fistula koroner $^{3}$

\begin{tabular}{|l|}
\hline Kelas I \\
\hline $\begin{array}{l}\text { Dokter bedah terlatih dan berpengalaman dalam penyakit jantung kongenital sebaiknya melakukan operasi untuk penatalaksanaan pasien } \\
\text { dengan fistula arterivena koroner. (C) }\end{array}$ \\
\hline Penutupan transkateter fistula arteri koroner sebaiknya dilakukan hanya pada pusat pelayanan dengan pengalaman dalam melakukan prosedur \\
tersebut. (C) \\
\hline $\begin{array}{l}\text { Penelusuran perjalanan fistula transkateter dan akses ke drainase distal sebaiknya dilakukan pada semua pasien dengan murmur kontinyu } \\
\text { dan telah diketahui memiliki fistula. (C) }\end{array}$ \\
\hline
\end{tabular}


merupakan pemeriksaan yang memiliki resolusi tinggi dan aman sebagai alternatif angiografi koroner dalam mendiagnosis fistula arteri koroner.

\section{Daftar Pustaka}

1. Davies $S$. Clinical presentation and diagnosis of coronary artery disease: stable angina. Br Med Bull. 2001; 59 (1): 17-27. doi: $10.1093 / \mathrm{bmb} / 59.1 .17$

2. Spektor G, Gehi A, Love B, Sharma S, Fuster V. A case of symptomatic coronary artery fistula. Nature Clin Practice Cardiovasc Med. 2006; 3(12):689-92. Doi:10.1038/ncpcardio0709

3. Warnes C, Bashore T, Dearani J, Graham T, Hunt S, Landzberg $\mathrm{M}$, et al. ACC/AHA guidelines for the management of adults with congenital heart disease. Circulation. 2008;118:e714-e833. Doi: $10.1161 /$ circualtionaha. 108.190690

4. Latson L. Coronary artery fistula: how to manage them. Cath Cardiovasc Int. 2007;70:110-16. Doi:10.1002/ccd.21125

5. Ata Y, et al. Coronary arteriovenous fistulas in the adults: natural history and management strategies. J Cardiothoracic Surg. 2009;6:62

6. Liberthson R, Sagar K, Berkoben J, Weintraub R, Levine F. Congenital coronary arteriovenous fistula. Report of 13 patients, review of theliterature and delineation of management. Circulation. 1979;59:849-54
7. Fahey JT, Asnes J. Coronary recanalization due to presumed thrombosis following surgical ligation of a large righ coronary artery to right ventricle fistula. Congenit Heart Dis. 2008;3:29598

8. Luo et al. Coronary arterial fistulas. Am J Med Sci. 2006;332:7084

9. Okwuosa TM, Gundeck EL, Ward RP. Coronary to pulmonary artery fistula: diagnosis by transesophageal echocardiography. Echocardiography. 2006;23(1):62-4

10. Qureshi SA. Coronary arterial fistulas. Orphanet J Rare Dis. 2006;1:1-6

11. Krishnamoorthy KM, et al. Transesophagial echocardiography for the diagnosis of coronary arteriovenous fistula. Int J Cardiol. 2004;96(2):281-3

12. Angelini $\mathrm{P}$, et al. Coronary artery anomalies, current clinical issues definitions, classification, incidence, clinical relevance, and treatment guidelines. Tex Heart Inst J. 2002;29:271-78

13. Gowda RM, Vasvada BC, Khan IA. Coronary artery fistulas: clinical and theurapeutic considerations. Int J Cardiol. 2006;107:7-10

14. Schmid M. Visualization of coronary artery anomalies by contrast-enchanced multi-detector row spiral computed tomography. Int J Cardiol. 2005; 111:430-35.

15. Balanescu $S$ et al. Coronary artery fistulas: clinical consequences and methods of closure. A literature reviews. Ital Heart J.2001;2:669-76 